Jurnal IImu Keperawatan Medikal Bedah 3 (1), Mei 2020, 1-76

ISSN 2338-2058 (print), ISSN 2621-2986 (online)

\title{
Hubungan antara Usia dan Lama Operasi dengan Hipotermi pada Pasien Paska Anestesi Spinal di Instalasi Bedah Sentral
}

\author{
Widiyono $^{1}$, Suryani ${ }^{2}$, Ari Setiyajati ${ }^{3}$ \\ ${ }^{1}$ Departemen Keperawatan Medikal Bedah, Program Studi Ilmu Keperawatan, Fakultas Sains, Teknologi dan \\ Kesehatan, Universitas Sahid Surakarta, Indonesia \\ ${ }_{2}^{2}$ Program Studi Ilmu Keperawatan, Fakultas Sains, Teknologi dan Kesehatan, Universitas Sahid Surakarta, \\ Indonesia \\ 3 Perawat RSUD Moewardi Surakarta, Minat Medikal Bedah, Program Studi Ilmu Keperawatan Keperawatan \\ Universitas Sahid Surakarta, Indonesia \\ Corresponding Author: widiyono2727@gmail.com
}

\begin{abstract}
Abstrak
Anestesi spinal adalah teknik yang sering dilakukan dalam tindakan operasi, meskipun banyak dilaporkan kejadian komplikasi setelah menjalani anestesi. Komplikasiyang sering terjadi diantaranya adalah hipotermi. Dampak negatif hipotermi terhadap pasien, antara lain risiko perdarahan meningkat, iskemia miokardium, pemulihan paska anestesi yang lebih lama, gangguan penyembuhan luka, serta meningkatnya risiko infeksi. Penelitian ini bertujuan untuk mengetahui hubungan antara usia dan lama operasi dengan hipotermi paska anestesi spinal di Instalasi Bedah Sentral. Penelitian ini menggunakan deskriptif korelasional dengan rancangan cross sectional. Sampel sebanyak 53 orang dengan teknik purposive sampling. Teknik analisis data menggunakan uji Chi-Square. Hasil penelitian menunjukkan mayoritas responden paska anestesi spinal berusia lansia sebanyak 22 orang $(41,8 \%)$ dan lama operasi responden paska anestesi spinal tergolong cepat yaitu sebanyak 33 orang (62,3\%). Ada hubungan antara faktor usia $(\mathrm{p}=0,028)$ dan lama operasi $(\mathrm{p}=0,005)$ dengan hipotermi paska anestesi spinal. Kesimpulan penelitian ini yakni adanya hubungan antara usia dan lama operasi dengan hipotermi pada pasien paska anestesi spinal.
\end{abstract}

Kata kunci: hipotermi, instalasi bedah sentral, lama operasi, spinal anastesi, usia

\begin{abstract}
Spinal anesthesia is a technique that is often performed in surgery, although many reported the incidence of complications after undergoing anesthesia. Complications that often occur include hypothermia. The negative effects of hypothermia on patients include the risk of increased bleeding, myocardial ischemia, longer post-anesthesia recovery, impaired wound healing, and increased risk of infection. This study aims to determine the relationship of age and duration of surgery with hypothermia after spinal anesthesia at the Central Surgical Installation. This research uses descriptive correlational with cross sectional design. A sample of 53 people with a purposive sampling technique. Data analysis techniques using the Chi-Square test. The results showed majority of respondents who after taking spinal anesthesia is elderly were 22 people (41.8\%). The duration of operation of post spinal anesthesia was relatively fast as many as 33 people $(62.3 \%)$. There is a relationship between age $(p=0.028)$ and duration of surgery $(p=0.005)$ with hypothermia after spinal anesthesia. The conclusion of the study is any significant relationship between age and duration of surgery with hypothermia after spinal anesthesia.
\end{abstract}

Widiyono, Suryani, Setiyajati / Hubungan antara usia dan lama operasi berhubungan dengan... 55 
Jurnal IImu Keperawatan Medikal Bedah 3 (1), Mei 2020, 1-76

ISSN 2338-2058 (print), ISSN 2621-2986 (online)

Keywords: hypothermia, central surgical installation, duration of surgery, spinal anesthesia, age PENDAHULUAN

Kemajuan teknologi membuat pelayanan kesehatan menjadi semakin berkembang, terutama dalam hal anestesi. Pemberian anestesi adalah upaya menghilangkan nyeri dengan sadar (spinal anestesi) atau tanpa sadar (general anestesi) guna menciptakan kondisi optimal bagi pelaksanaan pembedahan (Sabiston, 2011). Spinal anestesi merupakan teknik yang banyak dilakukan pada berbagai macam prosedur pembedahan (Islami, 2012). Lebih dari 80\% operasi dilakukan mempergunakan teknik spinal anestesi dibandingkan dengan general anestesi (Harahap, 2014). Anestesi memiliki 3 fase, yaitu pre anestesi, intra anestesi dan pasca anestesi (Mangku \& Senapathi, 2010). Periode pemulihan pasca anestesi dikenal sebagai waktu dengan risiko tinggi untuk terjadinya komplikasi. Ditemukan 2,5\% pasien mengalami komplikasi setelah menjalani anestesi (Mahalia, 2012). Salah satu komplikasi yang muncul setelah tindakan anestesi adalah hipotermi (Setiyanti, 2016).

Hipotermi terjadi karena agen dari obat general anestesi menekan laju metabolisme oksidatif yang menghasilkan panas tubuh, sehingga mengganggu regulasi panas tubuh. Spinal anestesi dapat menghilangkan proses adaptasi serta mengganggu mekanisme fisiologi pada fungsi termoregulasi (Harahap, 2014). Setiap pasien yang menjalani operasi berada dalam risiko mengalami kejadian hipotermi (Setiyanti, 2016). Penelitian yang dilakukan oleh Harahap (2014) di RS Hasan Sadikin Bandung, telah membuktikan dampak negatif hipotermi terhadap pasien antara lain risiko perdarahan meningkat, iskemia miokardium, pemulihan pasca anestesi yang lebih lama, gangguan penyembuhan luka, serta meningkatnya risiko infeksi. Penelitian ini menyebutkan bahwa angka kejadian hipotermi saat pasien berada di IBS (Instalasi Bedah Sentral) sebanyak $87,6 \%$.

Penelitian Mubarokah (2017), menjelaskan bahwa semakin tinggi usia responden maka semakin tinggi risiko mengalami kejadian hipotermi. Spinal anestesi yang dilakukan pada pasien usia lansia juga dapat menyebabkan pergeseran pada ambang batas termoregulasi dengan derajat yang lebih besar dibandingkan dengan pasien yang berusia muda. (Harahap, 2014). Kejadian hipotermia lebih banyak ditemukan pada responden yang menjalani operasi besar (>60 menit) (Mahalia, 2012). Hal ini sesuai dengan teori yang menyatakan bahwa menggigil merupakan respon terhadap hipotermia selama pembedahan antara suhu darah dan kulit dengan suhu inti 
tubuh. Pembedahan dengan spinal anestesi yang lama meningkatkan terpaparnya tubuh dengan suhu dingin sehingga menyebabkan perubahan temperatur tubuh (Putzu, et al., 2007).

Peran perawat dalam upaya pencegahan komplikasi anestesi terdiri dari pemantauan/pengkajian pasca anestesi dan perawatan/penatalaksanaan pasien pasca anestesi (Latief, 2011). Hal-hal yang perlu diperhatikan pada pasien yang menjalani spinal anestesi adalah keadaan pernapasan, kardiovaskuler, keseimbangan cairan, sistem persarafan, perkemihan, dan gastrointestinal. Pemantauan yang optimal dan penanganan pasien pasca anestesi yang dilakukan dengan baik dapat mencegah terjadinya komplikasi pasca anestesi pada pasien.

Studi pendahuluan yang dilakukan pada tanggal 12 November 2018 diketahui bahwa, jumlah pasien yang dioperasi pada bulan Oktober 2018 sebanyak 397 orang, dengan operasi spinal anestesi rata-rata 178 orang. Oleh karena itu, peneliti memilih responden yang menjalani operasi dengan spinal anestesi sebagai sampel yang digunakan untuk penelitian. Pada Oktober 2018, fenomena hipotermi di ruang Instalasi Bedah Sentral sebanyak 7 pasien mengalami hipotermi (suhu tubuh $34.8 \mathrm{oC}-35.5 \mathrm{oC}$ ) dari 12 pasien yang dilakukan operasi dengan spinal anestesi, atau sebanyak $58,3 \%$.

Berdasarkan latar belakang di atas, peneliti tertarik untuk meneliti berkenaan dengan hubungan antara faktor usia dan lama operasi dengan hipotermi pasca spinal anestesi di Instalasi Bedah Sentral. Tujuan penelitian ini adalah untuk mengetahui hubungan usia dan lama operasi dengan hipotermia paska anestesi spinal di Instalasi Bedah Sentral.

\section{METODE PENELITIAN}

Jenis penelitian ini adalah deskripsi analitik dengan rancangan cross sectional. Adapun faktor yang berhubungan dengan hipotermia paska anestesi spinal dalam penelitian ini adalah faktor usia dan lama operasi. Tempat penelitian dalam penelitian ini dilakukan di Instalasi Bedah Sentral. Waktu penelitian adalah masa dari keseluruhan dari jalannya penelitian yang berkaitan dengan pengambilan data saat penelitian. Penelitian ini sudah dilaksanakan pada tanggal 12 Maret - 15 April 2019. 
Populasi dalam penelitian ini adalah seluruh pasien dengan spinal anestesi di Instalasi Bedah Sentral. Sampel dalam penelitian ini adalah 53 responden. Peneliti menggunakan teknik purposive sampling. Kriteria inklusi dalam penelitian ini: pasien yang dioperasi dengan spinal anestesi, pasien dengan usia 17-55 tahun, pasien elektif dengan spinal anestesi, pasien yang memiliki IMT antara 18,5 kg/m² $-29,9 \mathrm{~kg} / \mathrm{m}^{2}$, dan pasien yang memiliki MAP : $70-110 \mathrm{mmHg}$. Kriteria eksklusi adalah pasien dengan gangguan penurunan kesadaran dan pasien dengan operasi yang membuka regio dada dan abdomen.

Instrumen yang digunakan untuk pengumpulan data pada penelitian ini adalah termometer aksila merek Philips seri MX450 yang sudah dikalibrasi. Analisis univariat menggunakan analisis distribusi frekuensi sedangkan analisis bivariat menggunakan analisis chisquare $\left(\mathrm{X}^{2}\right)$. Penelitian ini sudah mendapatkan ethical clearance dari Rumah Sakit yang bersangkutan sehingga proses pelaksanaannya berpedoman pada prinsip etik penelitian.

\section{HASIL DAN PEMBAHASAN}

\section{A. Hasil Penelitian}

Penelitian ini dilakukan pada fase pre anestesi (pengkajian/ observasi) dan pasca anestesi (mengukur suhu tubuh responden dan menghitung lama operasi). Karakteristik responden dapat diketahui dalam tabel 1.

Tabel 1. Distribusi Frekuensi berdasarkan Karakteristik Responden Penelitian di Ruang IBS Bulan Maret - April $2019(\mathrm{n}=53)$

\begin{tabular}{|c|c|c|}
\hline Variabel & Frekuensi & Persentase $(\%)$ \\
\hline \multicolumn{3}{|l|}{ Jenis Kelamin } \\
\hline Laki-laki & 25 & 47,2 \\
\hline Perempuan & 28 & 52,8 \\
\hline \multicolumn{3}{|l|}{ IMT } \\
\hline Kurang & 1 & 1,9 \\
\hline Ideal & 27 & 50,9 \\
\hline Lebih & 23 & 43,4 \\
\hline Gemuk & 2 & 3,8 \\
\hline \multicolumn{3}{|l|}{ Usia } \\
\hline $17-25$ tahun (Remaja) & 11 & 20,8 \\
\hline $26-45$ tahun (Dewasa) & 20 & 37,7 \\
\hline 46 - 65 tahun (Lansia) & 22 & 41,5 \\
\hline
\end{tabular}


Jurnal IImu Keperawatan Medikal Bedah 3 (1), Mei 2020, 1-76

ISSN 2338-2058 (print), ISSN 2621-2986 (online)

\begin{tabular}{lcc}
\hline Variabel & Frekuensi & Persentase (\%) \\
\hline Lama Operasi & & \\
Cepat $(<1$ jam $)$ & 33 & 62,3 \\
Sedang $(1-2$ jam $)$ & 19 & 35,8 \\
\hline Lama $(>2$ jam $)$ & 1 & 1,9 \\
\hline Hipotermi $($ Suhu $)$ & 33 & 62,3 \\
Hipotermi $\left(<36^{\circ} \mathrm{C}\right)$ & 20 & 37,7 \\
Tidak Hipotermi $\left(\geq 36^{\circ} \mathrm{C}\right)$ & 53 & 100 \\
\hline
\end{tabular}

Diketahui dari tabel 1 tersebut didapatkan bahwa jenis kelamin perempuan merupakan jumlah dominan, IMT paling banyak adalah IMT dengan kataogori ideal, mayoritas tergolong lansia, dari lama operasi mayoritas tergolong cepat dan dari kejadian hipotermi mayoritas responden tergolong hipotermi.

Analisis bivariat bertujuan untuk menjelaskan hubungan antar variabel yang diteliti. Hal ini dapat dijelaskan sebagai berikut :

a. Hubungan antara Usia dengan Hipotermi Paska Anestesi Spinal di Instalasi Bedah Sentral RS. Indriati Solo Baru

Tabel 2. Hasil Crosstab dan Analisis Chi-Square $\left(\chi^{2}\right)$

\begin{tabular}{|c|c|c|c|c|c|c|c|c|}
\hline \multirow[b]{2}{*}{ Usia } & \multicolumn{6}{|c|}{ Hipotermi } & \multirow[t]{2}{*}{$\chi^{2}$} & \multirow{2}{*}{$\begin{array}{c}p- \\
\text { value }\end{array}$} \\
\hline & Hipotermi & $\%$ & $\begin{array}{c}\text { Tidak } \\
\text { Hipotermi }\end{array}$ & $\%$ & Total & $\%$ & & \\
\hline Remaja & 4 & 7,5 & 7 & 13,2 & 11 & 20,8 & & \\
\hline Dewasa & 11 & 20,8 & 9 & 17,0 & 20 & 37,7 & 7,170 & 0,028 \\
\hline Lansia & 18 & 34,0 & 4 & 7,5 & 22 & 41,5 & & \\
\hline Total & 33 & 62,3 & 20 & 37,7 & 53 & 100,0 & & \\
\hline
\end{tabular}

Berdasarkan tabel 2, diketahui nilai chi-square hitung sebesar 7,170 dengan nilai probabilitas 0,028 ( $p$ value $<0,05$ ), sehingga Ha diterima dan Ho ditolak, artinya bahwa terdapat hubungan yang signifikan antara usia dengan kejadian hipotermi paska anestesi spinal di Instalasi Bedah Sentral. 
Jurnal IImu Keperawatan Medikal Bedah 3 (1), Mei 2020, 1-76

ISSN 2338-2058 (print), ISSN 2621-2986 (online)

b. Hubungan antara Lama Operasi dengan Hipotermi Paska Anestesi Spinal di Instalasi Bedah Sentral RS. Indriati Solo Baru

Tabel 3. Hasil Crosstab dan Analisis Chi-Square $(\chi 2)$

\begin{tabular}{|c|c|c|c|c|c|c|c|c|}
\hline \multirow[b]{2}{*}{$\begin{array}{l}\text { Lama } \\
\text { Operasi }\end{array}$} & \multicolumn{6}{|c|}{ Hipotermi } & \multirow[b]{2}{*}{$\chi^{2}$} & \multirow[b]{2}{*}{$p$-value } \\
\hline & Hipotermi & $\%$ & $\begin{array}{c}\text { Tdk } \\
\text { Hipotermi }\end{array}$ & $\%$ & Total & $\%$ & & \\
\hline Cepat & 26 & 49,1 & 7 & 13,2 & 33 & 62,3 & & \\
\hline Sedang & 7 & 13,2 & 12 & 22,6 & 19 & 35,8 & 10,711 & 0,005 \\
\hline Lama & 0 & 0,0 & 1 & 1,9 & 1 & 1,9 & & \\
\hline Total & 33 & 62,3 & 20 & 37,7 & 53 & 100,0 & & \\
\hline
\end{tabular}

Berdasarkan tabel 3, diketahui nilai chi-square hitung sebesar 10,711 dengan nilai probabilitas 0,005 $(p<0,05)$, sehingga Ha diterima dan Ho ditolak, artinya bahwa terdapat hubungan yang signifikan antara lama operasi dengan kejadian hipotermi paska anestesi spinal di Instalasi Bedah Sentral RS Indriati Solo Baru.

Tabel 4. Ringkasan Hasil Uji Regresi Logistik Hubungan antara Usia dan Lama Operasi dengan Hipotermi pada Pasien Paska Anestesi Spinal

\begin{tabular}{clcc}
\hline No & Faktor-Faktor & P Wald & Exp (B) \\
\hline 1 & Usia & 0.025 & 8.985 \\
2 & Lama Operasi & 1.000 & 0 \\
\hline
\end{tabular}

Pada table 4 di atas faktor yang berkontribusi terhadap hipotermi adalah usia dengan koefisien p 0.025 dalam hasil analisis tersebut didapat juga bahwa nilai odds ratio (Exp. B) sebesar 8.985 artinya bahwa responden yang semakin tua lebih berisiko 8.985 kali terjadi hipotermi. Selain itu nilai Nagelkerke $R$ square adalah 0.506 hal ini dapat diartikan adanya pengaruh yang signifikan antara usia pasien dengan terjadinya hipotermi sebesar $50.6 \%$.

\section{B. Pembahasan}

Pada teori Mangku \& Senapathi (2010), beberapa faktor yang berhubungan dengan hipotermi pasca spinal anestesi yaitu suhu kamar operasi, cairan infus, cairan pencuci rongga, kondisi pasien (IMT, usia, jenis kelamin), obat anestesi, dan lama operasi. Hipotermi juga terjadi karena kombinasi dari tindakan anestesi dan tindakan operasi yang dapat menyebabkan gangguan fungsi dari pengaturan suhu tubuh yang akan menyebabkan penurunan suhu inti tubuh I care temperature (Yulianto \& Budiono, 2011).

Widiyono, Suryani, Setiyajati / Hubungan antara usia dan lama operasi berhubungan dengan... 60 
Jurnal IImu Keperawatan Medikal Bedah 3 (1), Mei 2020, 1-76

ISSN 2338-2058 (print), ISSN 2621-2986 (online)

Responden pada penelitian ini lebih banyak yang berjenis kelamin perempuan daripada laki-laki. Hasil penelitian menunjukkan bahwa jenis kelamin perempuan lebih banyak mengalami hipotermi dibanding laki-laki. Hal ini sesuai dengan penelitian yang dilakukan Harahap (2014), angka hipotermi lebih banyak terjadi pada perempuan daripada laki-laki, yaitu sebanyak 51,2\%. Penelitian yang dilakukan Rosjidi dan Isro'ain (2014) juga mendapatkan hasil bahwa perempuan lebih rentan terserang penyakit/ komplikasi daripada laki-laki. Semua itu disebabkan adanya perbedaan biologis dan fungsi biologis yang ada pada perempuan dan lakilaki yang tidak dapat dipertukarkan (Hungu, 2010).

Hasil penelitian diketahui bahwa dilihat dari Indeks Massa Tubuh responden mayoritas mempunyai IMT tergolong ideal yaitu sebanyak 27 orang (50,9\%).Hasil penelitian menunjukkan responden terbanyak pada kategori IMT normal/ideal, tetapi responden dengan IMT kurus paling banyak frekuensi dan persentasenya dalam mengalami hipotermi pasca spinal anestesi dibanding pasien dengan IMT normal dan gemuk. Hal itu terjadi karena spinal anestesi mempengaruhi ketiga elemen termoregulasi yang terdiri atas elemen input aferen, pengaturan sinyal di daerah pusat dan juga respon eferen. Spinal anestesi dapat juga menghilangkan proses adaptasi serta mengganggu mekanisme fisiologi lemak/ kulit pada fungsi termoregulasi yaitu menggeser batas ambang untuk respons proses vasokonstriksi,menggigil, vasodilatasi dan juga berkeringat (Setiyanti, 2016).

Hasil pengumpulan data diketahui bahwa mayoritas responden berusia lansia (46 - 55 tahun). Berdasarkan hasil penelitian ini, semakin tinggi usia responden maka semakin tinggi risiko mengalami kejadian hipotermi. Hal itu sesuai dengan hasil penelitian yang dikemukakan Harahap (2014), pasien lanjut usia (lansia) termasuk ke dalam golongan usia yang ekstrem, merupakan risiko tinggi untuk terjadi hipotermi pada periode perioperatif. Anestesi spinal yang dilakukan pada pasien usia lansia juga dapat menyebabkan pergeseran pada ambang batas termoregulasi dengan derajat yang lebih besar dibandingkan dengan pasien yang berusia muda.

Hasil penelitian diketahui bahwa dilihat dari lama operasi, mayoritas tergolong cepat yaitu kurang dari 1 jam sebanyak 33 orang (62,3\%). Lama operasi dalam penelitian ini dihitung sejak dibuatnya sayatan pertama (time out) sampai pasien dipindahkan ke ruang pemulihan yang dinyatakan dalam jam. Suhu ruangan operasi di Rumah Sakit Indriati Solobaru dibuat konstan 
Jurnal IImu Keperawatan Medikal Bedah 3 (1), Mei 2020, 1-76

ISSN 2338-2058 (print), ISSN 2621-2986 (online)

180C. Menurut Majid, Judha \& Istianah (2011) hipotermi dialami pasien karena terpaparnya tubuh terlalu lama dengan suhu rendah kamar di ruang operasi $(<26,60 \mathrm{C})$. Selain itu, pasien yang menjalani operasi di Rumah Sakit Indriati Solobaru jarang menggunakan selimut penghangat selama durante operasi sampai di IBS, sehingga tubuh pasien lebih banyak terpapar dengan suhu ruangan yang dingin. Depkes RI (2008), menyatakan durasi pembedahan yang lama akan menyebabkan tindakan anestesi menjadi lama dan menambah waktu terpaparnya tubuh terhadap suhu dingin di ruang operasi.

Tindakan anestesi spinal dapat menghilangkan proses adaptasi serta mengganggu mekanisme fisiologi pada fungsi termoregulasi (Buggy, 2010). Spinal anestesia juga memengaruhi ketiga elemen termoregulasi yang terdiri atas elemen input aferen, pengaturan sinyal di daerah pusat dan juga respons eferen, serta menggeser batas ambang untuk respons proses vasokonstriksi, menggigil, vasodilatasi, dan juga berkeringat. Selama anestesia, ambang termoregulasi menjadi lebih rendah pada pasien geriatri bila dibandingkan dengan pasien yang berusia muda, yaitu sekitar 10C. Sebagai konsekuensi, maka suhu tubuh pasien selama pembedahan menjadi poikilotermik, yaitu akan mengikuti suhu lingkungan. Hampir semua jenis obat-obat anestesia mengganggu respons termoregulasi, misalnya lidokain, bupivakain, dan tetrakain adalah agen anestesi lokal yang utama digunakan untuk blockade spinal. Lidokain efektif untuk 1 jam, dan bupivacaine serta tetrakain efektif untuk 2 jam sampai 4 jam (Reeder, S., 2011).

Pada akhir anestesi dengan lidokain, bupivakain dan tetrakain kadang-kadang menimbulkan hipotermi sampai menggigil. Hal itu disebabkan karena efek obat anestesi yang menyebabkan gangguan termoregulasi (Aribowo, 2012). Semua obat anestesia umum memengaruhi termoregulasi dengan tingkatan yang hampir sama. Penggunaan lidokain sebagai analgesia intraoperatif dapat menurunkan suhu tubuh pascaoperasi rata-rata sebesar $0,80 \mathrm{C}$. Lidokain diduga mempunyai efek blokade panas yang dihasilkan oleh proses metabolisme, sehingga terjadi penurunan suhu pascaoperasi. bupivakain akan menurunkan ambang vasokonstriksi dan pengeluaran keringat.

Hipotermia perioperatif akan mempengaruhi metabolisme berbagai obat-obatan anestesia yang disebabkan enzim-enzim yang mengatur fungsi organ dan juga durasi obat yang sangat 
Jurnal IImu Keperawatan Medikal Bedah 3 (1), Mei 2020, 1-76

ISSN 2338-2058 (print), ISSN 2621-2986 (online)

sensitif terhadap perubahan suhu. Kelarutan obat anestesia di dalam plasma akan meningkat, sehingga saat dalam keadaan equilibrium, obat yang terdistribusi di dalam tubuh akan lebih banyak. Masa perawatan saat di ruang pemulihan rata-rata menjadi bertambah pada pasien hipotermia (Harahap, 2014). Hasil penelitian ini diperkuat oleh penelitian yang dilakukan oleh Mulyati (2013) yang menyakana bahwa angka kejadian hipotermi pada pasien lansia pasca operasi sebanyak 50 pasien $(83,33 \%)$,

Berdasarkan uji hipotesis dengan uji analisis regresi logistik diketahui bahwa usia merupakan faktor risiko terjadinya hipotermi dengan koefisien p $0.025<0.05$ dan nilai odds ratio sebesar 8.985 artinya bahwa responden yang semakin tua lebih berisiko 8.985 kali terjadi hipotermi. Hasil penelitian ini sejalan dengan Yang et al. (2015) bahwa prevalensi hipotermi dengan bertambahnya usia sebesar 1.2 kali lebih berisiko dibandingkan dengan usia yang lebih muda. Hasil penelitian menunjukkan bahwa seiring bertambahnya usia pasien, prevalensi hipotermia meningkat. Prevalensi hipotermia (33\%) pada kelompok senior (usia $\geq 60$ tahun) menduduki peringkat tertinggi di antara kelompok lain.

Analisis regresi logistik menunjukkan korelasi positif antara hipotermia dan usia. Karena pasien yang lebih tua memiliki lebih sedikit lemak subkutan, tonus otot istirahat yang lebih rendah, luas permukaan tubuh yang lebih besar, dan tingkat metabolisme yang lebih rendah, kemampuan mereka untuk secara efektif mengatur dan mempertahankan suhu tubuh normal lemah, bahkan dalam keadaan non-anestesi (Yang et al., 2015). Ketika perubahan suhu sekitar, tindakan termoregulasi (seperti vasokonstriksi dan menggigil) lansia secara signifikan lebih lemah daripada yang muda. Selain itu, efek anestesi umum melemahkan kemampuan termoregulasi tubuh, dan hipotermia lebih mungkin terjadi. Lama operasi pada analisis multivariat ini diketahui tidak berisiko terhadap kejadian hipotermi ( $\mathrm{p}>0,05)$, hal ini dimungkinkan karena pada penelitian ini pasien yang lama operasinya lebih dari 2 jam hanya ada 1 pasien dan tidak mengalami hipotermi. 
Jurnal Ilmu Keperawatan Medikal Bedah 3 (1), Mei 2020, 1-7

ISSN 2338-2058 (print), ISSN 2621-2986 (online)

\section{KESIMPULAN}

Dari hasil analisis variabel usia dan lama operasi terhadap kejadian hipotermi dengan hasil uji Chi-Square di dapatkan nilai $p<0,05$ artinya terdapat hubungan antara faktor usia $(\mathrm{p}=0,028)$ dan lama operasi $(\mathrm{p}=0,005)$ dengan hipotermi paska anestesi spinal.

\section{DAFTAR PUSTAKA}

Aribowo, N. K. (2012). Hubungan lama tindakan anestesi dengan waktu pulih sadar pasien paska general anestesi di IBS RSUD Muntilan Magelang. Skripsi DIV Keperawatan Poltekkes Kemenkes Yogyakarta.

Buggy, D. J., \& Crossley, A. W. A. (2010). Thermoregulation, mild perioperaatie hypothermia and post anesthetic shivering. Br.J Anaesth 84(5): 615-628.

Depkes RI. (2009). Profil kesehatan Indonesia. Jakarta.

Harahap, A. M., Kadarsah, R.K., dan Oktaliansah, E. (2014). Angka kejadian hipotermia dan lama perawatan di IBS pada pasien geriatri pascaoperasi elektif Bulan Oktober 2011Maret 2012 di Rumah Sakit Dr.Hasan Sadikin Bandung. Jurnal Anestesi Perioperatif. Volume 2(1) No: 36-44. Fakultas Kedokteran Universitas Padjadjaran.

Hungu. (2009). Demografi kesehatan Indonesia. Jakarta: Grasindo.

Indriati, E. (2010). Antropometri untuk kedokteran, keperawatan, gizi, dan olahraga. Yogyakarta: PT. Citra Aji Parama.

Islami, R. H. (2012). Pengaruh penggunaan ketamin terhadap kejadian menggigil paska anestesi umum. Jurnal Medika Media Muda Karya Tulis Ilmiah. Semarang: Fakultas Kedokteran Universitas Diponegoro.

Latief, Said, Suryadi, Suryadi, A., Kartini., \& Dachlan, M. Ruswan. (2009). Petunjuk praktis anestesiologi (2 ed). Jakarta: Bagian Anestesiologi dan Terapi Intensif Fakultas Kedokteran Universitas Indonesia.

Mahalia, S. M. (2012). Efektivitas tramadol sebagai pencegah menggigil pasca anestesi umum. Jurnal Publikasi. Semarang: Fakultas Kedokteran, Universitas Diponegoro.

Majid, A., Judha, M., \& Istianah, U. (2011). Keperawatan perioperatif. Yogyakarta: Gosyen Publishing.

Mangku, G., \& Senapathi, T. G. A. (2010). Ilmu anestesia dan reanimasi. Jakarta: PT. Indeks.

Mubarokah, P.P. (2017). Faktor-faktor yang berhubungan dengan hipotermi pasca general anestesi di Instalasi Bedah Sentral RSUD Kota Yogyakarta. Jurnal Publikasi. Yogyakarta: Jurusan Keperawatan, Poltekes Kemenkes.

Widiyono, Suryani, Setiyajati / Hubungan antara usia dan lama operasi berhubungan dengan... 64 
Mulyati. (2013). Gambaran angka kejadian hipotermi dan lama perawatan di ruang pemulihan pada pasien lansia pasca operasi di Rumah Sakit Hasan Sadikin Bandung. Bandung: Jurnal Anestesi Perioperatif.

Putzu, M. 2007. Clinical complications, monitoring and management of perioperative mild hypothermia: anesthesiological features. Acta Biomed.Vol. 78: 163-9.

Reeder, S.J., Martin, L.L., \& Griffin, D.K. (2012). Keperawatan maternitas: kesehatan wanita, bayi, \& keluarga. 18th edn. Jakarta : Penerbit Buku Kedokteran EGC.

Rosjidi, C. H., dan Isro'ain. (2014). Buku ajar peningkatan tekanan intrakranial \& gangguan peredaran darah otak.Yogyakarta: Gosyen Publishing.

Sabiston, D. C. (2011). Buku ajar bedah. Jakarta : EGC.

Setiyanti, W. (2016). Efektifitas selimut alumunium foil terhadap kejadian hipotermi pada pasien post operasi RSUD Kota Salatiga. Jurnal Publikasi Ilmiah. Surakarta: S1 Keperawatan Stikes Kusuma Husada Surakarta.

Yang, Lu., Huang CY, Zhou ZB. (2015). Risk factors for hypothermia in patients under general anesthesia: Is there a drawback of laminar airflow operating rooms? A prospective cohort study. International Journal of Surgery. Volume 21, September 2015, Pages 14-17

Yulianto \& Budiono. (2011). Desain dan pembuatan inkubator berdasarkan distribusi temperature. Jurnal Gamma, Vol. 8, 1:140-147. 